\title{
AKTIVITAS ANTIBAKTERI EKSTRAK PERASAN DAUN MENGKUDU (Morinda citrifolia L.) TERHADAP Escherichia coli SECARA IN VITRO
}

\author{
Margareta Retno Priamsari ${ }^{1}$, Agastia Cicilia Wibowo ${ }^{2}$ \\ ${ }^{1,2}$ Politeknik Katolik Mangunwijaya Semarang \\ Program Studi Diploma Tiga Farmasi \\ 1marga_rhee@yahoo.co.id \\ 2agascicil@gmail.com \\ Email Korespensi: marga_rhee@yahoo.co.id
}

\begin{abstract}
ABSTRAK
Perasan daun mengkudu dapat menghambat pertumbuhan bakteri Escherichia coli. Hasil perasan daun mengkudu membutuhkan proses pemekatan menjadi ekstrak agar sediaan lebih stabil dalam proses penyimpanan. Tujuan dari penelitian ini untuk mengetahui aktivitas antibakteri dan besarnya konsentrasi hambat minimum ekstrak perasan daun mengkudu terhadap bakteri E.coli secara in vitro. Jenis penelitian eksperimental dengan rancangan acak lengkap satu arah. Ekstrak diperoleh dengan memekatkan perasan daun mengkudu. Parameter kontrol kualitas ekstrak meliputi organoleptis, rendemen, susut pengeringan, dan uji kualitatif senyawa flavonoid serta antrakuinon. Uji aktivitas antibakteri menggunakan metode disc diffusion dengan konsentrasi ekstrak 1,56\%; 3,12\%; 6,25\%; 12,5\%; dan 25\% dengan 3 kali replikasi. Kontrol positif amoksisilin dan kontrol negatif akuades. Daya hambat diketahui dari zona yang terbentuk di sekitar kertas cakram. Data yang diperoleh dianalisis statistik menggunakan Kruskall Wallis dilanjutkan Mann Whitney dengan taraf kepercayaan 95\%. Hasil penelitian menunjukkan bahwa variasi konsentrasi ekstrak perasan daun mengkudu berpengaruh secara signifikan $(\mathrm{p}<0,05)$. Zona hambat terbesar terlihat pada konsentrasi 25\% sebesar 10,16 mm dan termasuk kategori kuat. Daya hambat minimum dihasilkan pada konsentrasi 3,12 \% sebesar 2,50 mm dengan kategori penghambatan lemah.
\end{abstract}

Kata Kunci : Ekstrak perasan daun mengkudu, Escherichia coli, Disc Diffusion, KHM 


\title{
IN VITRO ANTIBACTERIAL ACTIVITY FROM LEAF EXTRACT FEEDING OF Morinda citrifolia L. AGAINST Escherichia coli
}

\begin{abstract}
Noni juice can inhibit the growth of Escherichia coli bacteria. Noni juice extraction needs concentration to extract so that the preparation is more stable in the storage process. The purpose of this study was to determine the antibacterial activity and the amount of the minimum inhibitory concentration of noni juice extract from $E$. coli bacteria in vitro. This type of experimental research with a completely randomized one-way design. The extract was obtained by concentrating the Noni leaf extract. Extract quality control parameters include organoleptic, yield, drying shrinkage, and qualitative tests of flavonoid and anthraquinone compounds. Antibacterial activity test using the disc diffusion method with an extract concentration of $1.56 \% ; 3.12 \% ; 6.25 \%$; 12.5\%; and 25\% with 3 replications. Positive control of amoxicillin and negative control of distilled water. Inhibition is known from the zone formed around the paper disc. The data obtained were statistically analyzed using Kruskall Wallis followed by Mann Whitney with a 95\% confidence level. The results showed that the variation in the concentration of the noni juice extract had a significant effect $(p<0.05)$. The biggest inhibitory zone was seen at $25 \%$ concentration of $10.16 \mathrm{~mm}$ and included in the strong category. The minimum inhibitory power was produced at a concentration of $3.12 \%$ at $2.50 \mathrm{~mm}$ with a weak treatment category.
\end{abstract}

Keywords : Noni juice extract, Escherichia coli, Disc Diffusion, MIC

\section{PENDAHULUAN}

Infeksi saluran kemih (ISK) adalah infeksi yang disebabkan oleh bakteri Enterobacteriacea yang terjadi pada sistem saluran kemih. Angka kejadian terjadinya ISK di Indonesia berkisar 39\%-60\% (Sari, 2018). Bakteri Enterobacteriaceae yang dominan menyebabkan ISK adalah Escherichia coli. Escherichia coli merupakan bakteri gram negatif yang berkoloni di saluran pencernaan manusia dan dapat menyebabkan penyakit seperti diare, sepsis, meningitis, dan infeksi saluran kemih (Jawetz, 2014). Salah satu penanganan bakteri adalah dengan pemberian antibakteri.

Pemberian antibakteri dalam pengobatan penyakit ISK umumnya direkomendasikan selama 7-14 hari. Antibakteri oral dalam penangan kasus ISK yang banyak digunakan antara lain: trimetoprim (TMP), kotrimoksazol (TMP \& sulfametoksazol), sefalosporin, atau amoksisilin/asam klavulanat (Wahyudi, 2015). Penggunaan antibakteri yang tidak tepat akan 
menimbulkan berbagai permasalahan seperti pengobatan kurang efektif, peningkatan resiko terhadap keamanan pasien, resistensi bakteri terhadap antibakteri dan tingginya biaya pengobatan. Salah satu upaya dalam mengatasi hal tersebut adalah dengan menggunakan alternatif pengobatan berbahan dari alam atau obat tradisional.

Salah satu tanaman obat tradisional yang berpotensi sebagai antibakteri adalah mengkudu (Morinda citrifolia L.). Penelitian Kameswari, dkk (2013), melaporkan bahwa perasan daun mengkudu mengandung senyawa flavonoid dan antrakuinon yang berperan terhadap pertumbuhan bakteri E. coli. Hasil penelitian menunjukkan perasan daun mengkudu mampu menghambat pertumbuhan bakteri E.coli dengan KHM sebesar 7,3 mm pada konsentrasi $25 \%$.

Metode perasan memiliki keuntungan yaitu alat yang digunakan tidak rumit dan proses pembuatan tidak memerlukan keahlian khusus. Namun metode perasaan juga memiliki kekurangan yaitu sari yang dihasilkan mudah ditumbuhi mikroba dan tidak dapat disimpan dalam jangka waktu lama sehingga diperlukan proses penyarian yang selalu baru (Wiradona, dkk., 2015). Jumlah sari yang dihasilkan juga cukup banyak sehingga volume yang harus dikonsumsi cukup besar. Berdasarkan kekurangan dari hasil ekstraksi perasan yang kurang stabil dalam proses penyimpanan dan kurang praktis dalam penggunaannya, maka perlu dilakukan alternatif bentuk sediaan lain, salah satunya dalam bentuk ekstrak perasan. Bentuk ekstrak dipilih karena memiliki keuntungan dapat disimpan dalam jangka waktu lama karena lebih stabil (Anief, 2010). Berkaitan dengan hal tersebut, maka dilakukan penelitian mengenai aktivitas antibakteri dan besaran Kadar Hambat Minimal (KHM) ekstrak perasan daun mengkudu terhadap bakteri $E$ coli secara in vitro.

\section{METODE PENELITIAN}

\section{Alat dan Bahan}

Alat yang digunakan dalam penelitian ini meliputi pisau, talenan, blender (Miyako), ayakan no 18, toples kaca, neraca analitik (Mettler Toledo), alumunium foil, mortir - stamper, waterbath, moisture analyzer (Ohaus), termometer, seperangkat alat gelas (Pyrex), kain flanel, cawan petri, pinset, pipet tetes, pipet volume, filler (Glasfirn), ose bulat, ose tajam, lampu spiritus, mikroskop (Olymphus), oven (Memmert), autoklaf (All American), inkubator (Memmert), mistar.

Bahan yang digunakan dalam penelitian ini meliputi ekstrak perasan daun mengkudu, akuades, toluena, $\mathrm{KOH}$, ammonia $(\mathrm{p})$, asam asetat glasial, $\mathrm{HCl}, \mathrm{H}_{2} \mathrm{O}_{2}$, Serbuk Mg (E. Merck), biakan bakteri Eschericia coli ATCC 25922, akuades steril, $\mathrm{NaCl}$ fisiologis 0,9\% (Otsuka), cakram $7 \quad \mathrm{~mm}$ (Whatmann No. 42), paperdisk

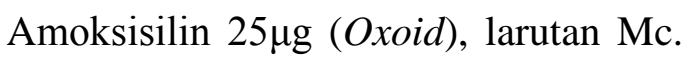
Farland, media Nutrient Agar (NA), akuabides.

\section{Rancangan Penelitian \\ Pembuatan Ekstrak Perasan Daun Mengkudu}


Ekstraksi daun mengkudu diperoleh dengan metode pemerasan. Daun mengkudu segar sebanyak 50 gram dicuci dengan air mengalir dan ditiriskan kemudian dilakukan perajangan. Daun mengkudu dimasukan blender dan ditambah akuades sebanyak $500 \mathrm{~mL}$ lalu diblender. Perlakuan ekstraksi diulang sebanyak 6 kali. Hasil disatukan dan dilakukan pemerasan dengan kain flanel. Hasil perasan kemudian dipekatkan di atas waterbath pada suhu $40-50^{\circ} \mathrm{C}$ hingga diperoleh ekstrak kental. Ekstrak kental dilakukan pengujian susut pengeringan menggunakan moisture analyzer pada suhu $105^{\circ} \mathrm{C}$ selama 10 menit. Pengujian dilanjutkan dengan identifikasi organoleptis dan perhitungan rendemen. Rendemen yang dihasilkan dihitung dengan cara:

$$
\text { Rendemen } \%=\frac{\text { Bobot ekstrak (gram) }}{\text { Bobot simplisia awal (gram) }} \times 100
$$

\section{Uji Kandungan Ekstrak Perasan}

\section{Daun Mengkudu}

a. Identifikasi senyawa flavonoid Identifikasi flavonoid dilakukan dengan uji shinoda. Serbuk $\mathrm{Mg}$ sejumlah $10 \mathrm{mg}$ dan 5 tetes $\mathrm{HCl}_{(\mathrm{p})}$ ditambahkan kedalam $2 \mathrm{~mL}$ larutan uji dalam tabung reaksi. Warna merah, kuning atau jingga yang muncul menunjukkan adanya senyawa flavonoid (Putra, dkk, 2014).

b. Identifikasi senyawa antrakuinon Identifikasi antrakuinon dilakukan dengan uji Borntrager dan modifikasi Borntrager. Pengujian Borntrager dilakukan dengan penambahan 0,3 $\mathrm{mL}$ larutan uji dilarutkan dalam 10 $\mathrm{mL}$ akuades, disaring dan filtrat diekstraksi dengan toluen, ditambah $\operatorname{ammonia}_{(\mathrm{p})} 1 \mathrm{~mL}$ dan dikocok. Warna merah yang terbentuk menunjukkan antrakuinon (Sirait, 2007).

Pengujian modifikasi Borntrager dengan menambah $5 \mathrm{~mL} \mathrm{KOH} \mathrm{0,5} \mathrm{N}$ dan $1 \mathrm{~mL} \mathrm{H} \mathrm{H}_{2} \mathrm{O}_{2}$ encer dalam $0,3 \mathrm{~mL}$ larutan uji. Ekstrak dipanaskan selama 5 menit dan disaring serta ditambah asam asetat glasial dan diekstraksi dengan toluen $5 \mathrm{~mL}$. Selanjutnya ditambahkan ammonia $_{(\mathrm{p})}$ 1 mL. Timbulnya warna merah menunjukkan senyawa antrakuinon (Sutriani, 2008).

\section{Penentuan Konsentrasi Ekstrak Perasan Daun Mengkudu}

Penentuan konsentrasi ekstrak perasan daun mengkudu diperoleh berdasarkan penelitian Kameswari (2013) dalam perasan daun mengkudu sebagai antibakteri terhadap bakteri E.coli. Penentuan konsentrasi yang digunakan dalam ekstrak perasan daun mengkudu sebesar 1,56\%; 3,12\%; $6,25 \%$; $12,5 \%$; dan $25 \%$.

\section{Uji Aktivitas Antibakteri Ekstrak Perasan Daun Mengkudu}

Uji aktivitas antibakteri ekstrak perasan daun mengkudu dilakukan dengan metode Kirby-Bauer. Pengujian dilakukan dengan mempersiapkan 
cawan petri steril yang terbagi menjadi 7 juring, yaitu sebagai kontrol negatif (akuades), kontrol positif (amoxicillin), dan lima konsentrasi ekstrak perasan daun mengkudu. Suspensi bakteri $1 \mathrm{~mL}$ dimasukkan ke dalam cawan petri kemudian ditambahkan media NA dan dihomogenkan. Cakram dimasukkan dalam larutan uji, ditiriskan dan ditempatkan pada setiap juring. Inkubasi dilakukan pada suhu $37^{\circ} \mathrm{C}$ selama 24 jam. Hasil pengamatan terlihat berupa zona bening yang terbentuk disekitar cakram dan diukur diameter zona hambat secara vertikal dan horizontal. Replikasi dilakukan 3 kali. Selanjutnya diameter yang terbentuk dihitung rata-ratanya, dianalisis dan digolongkan menurut Davis \& Stout (1971) pada tabel I berikut.

Tabel I. Nilai Standar Potensi Antibakteri Ketentuan Davis and Stout (1971)

\begin{tabular}{cc}
\hline Daerah hambat $(\mathrm{mm})$ & Potensi Antibakteri \\
\hline 20 atau lebih & Sangat Kuat \\
\hline $10-20$ & Kuat \\
\hline $5-10$ & Sedang \\
\hline Kurang dari 5 & Lemah \\
\hline
\end{tabular}

\section{Analisis Hasil}

Data berupa rata-rata diameter zona hambat dianalisis normalitas menggunakan metode Saphiro-wilk dan homogenitas dengan Levene statistic. Selanjutnya dianalisis dengan metode Kruskal Wallis dan dilanjutkan uji Mann-Whitney dengan taraf kepercayaan $95 \%$.

\section{HASIL DAN PEMBAHASAN}

Hasil yang didapatkan dalam proses pemerasan berupa sari perasan. Sari perasan berbentuk cairan. Warna hijau tua pada sari perasan daun mengkudu disebabkan kandungan klorofil (Rukmana, 2002). Hasil perasan yang didapatkan selanjutnya diuapkan di atas waterbath hingga diperoleh ekstrak kental dan dilakukan pengujian kontrol kualitas ekstrak.

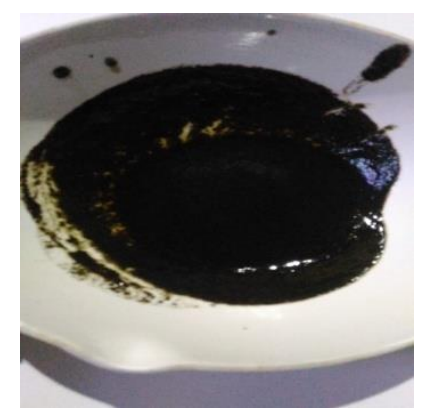

Gambar 1. Hasil Ekstrak Perasan Daun Mengkudu 
Hasil kontrol kualitas menunjukkan bahwa ekstrak perasan daun mengkudu telah memenuhi standar yang dipersyaratkan yaitu kurang dari $10 \%$ pada kadar susut pengeringan (Depkes, 2000).

Tabel II. Kontrol Kualitas Ekstrak Perasan Daun Mengkudu

\begin{tabular}{cll}
\hline No & Parameter Kontrol Kualitas & Hasil \\
\hline 1. & Organoleptis & \\
\hline & a. Konsistensi & Kental \\
\hline & b. Warna & Coklat kehitaman \\
\hline & c. Bau & Khas \\
\hline & d. Rasa & Pahit \\
\hline 2. & Susut Pengeringan & $6,83 \% \mathrm{~b} / \mathrm{b}$ \\
\hline 3. & Rendemen & $17,6 \% \% \mathrm{~b}$ \\
\hline
\end{tabular}

Data hasil uji kualitatif ekstrak perasaan daun mengkudu dapat dilihat pada Tabel III berikut.

Tabel III. Hasil Uji Kualitatif Ekstrak Perasaan Daun Mengkudu

\begin{tabular}{cccccc}
\hline Senyawa & Metode & Pustaka & Sebelum & Sesudah & Ket \\
\hline \multirow{5}{*}{ Antrakinon } & Brontrager & $\begin{array}{c}\text { Terbentuk } \\
\text { warna merah } \\
\text { (Sirait, 2007) }\end{array}$ & $\begin{array}{c}\text { Coklat } \\
\text { kehitaman }\end{array}$ & $\begin{array}{c}\text { Merah } \\
\text { kecoklatan }\end{array}$ & + \\
\cline { 2 - 6 } & Modifikasi & $\begin{array}{c}\text { Terbentuk } \\
\text { warna merah } \\
\text { Brontrager } \\
\text { Flavonoid }\end{array}$ & $\begin{array}{c}\text { Coklat } \\
\text { kehitaman }\end{array}$ & $\begin{array}{c}\text { Merah } \\
\text { kecoklatan }\end{array}$ & + \\
& Shinoda & $\begin{array}{c}\text { Terbentuk } \\
\text { warna } \\
\text { kuning/jingga } \\
\end{array}$ & $\begin{array}{c}\text { Coklat } \\
\text { kehitaman }\end{array}$ & Jingga & \\
\hline
\end{tabular}

Data hasil pengukuran zona hambat ekstrak perasan daun mengkudu konsentrasi $1,56 \%$; $3,12 \% ; 6,25 \% ; 12,5 \%$; dan $25 \%$ dan akuades sebagai kontrol negatif serta amoksilin sebagai kontrol positif dapat dilihat pada Tabel IV berikut.

Tabel IV. Hasil Rerata Diameter Zona Hambat Ekstrak Perasan Daun Mengkudu

\begin{tabular}{|c|c|c|c|c|}
\hline \multirow{2}{*}{ Perlakuan } & \multicolumn{3}{|c|}{ Diameter Zona Hambat (cm) } & \multirow{2}{*}{ Rerata \pm SD } \\
\hline & 1 & 2 & 3 & \\
\hline Kontrol negatif (akuades steril) & - & - & - & - \\
\hline
\end{tabular}




\begin{tabular}{|c|c|c|c|c|}
\hline $\begin{array}{l}\text { Ekstrak perasan daun } \\
\text { mengkudu } 1,56 \%\end{array}$ & - & - & - & - \\
\hline $\begin{array}{l}\text { Ekstrak perasan daun } \\
\text { mengkudu } 3,12 \%\end{array}$ & 1,50 & 3,00 & 3,00 & $2,50 \pm 0,86^{\mathrm{a}}$ \\
\hline $\begin{array}{l}\text { Ekstrak perasan daun } \\
\text { mengkudu } 6,25 \%\end{array}$ & 4,00 & 4,50 & 5,50 & $4,66 \pm 0,75^{b}$ \\
\hline $\begin{array}{l}\text { Ekstrak perasan daun } \\
\text { mengkudu } 12,5 \%\end{array}$ & 5,50 & 6,00 & 5,50 & $5,66 \pm 0,29^{\mathrm{c}}$ \\
\hline $\begin{array}{l}\text { Ekstrak perasan daun } \\
\text { mengkudu } 25 \%\end{array}$ & 9,50 & 10,00 & 11,00 & $\begin{array}{c}10,16 \pm 0,76 \\
\mathbf{c}\end{array}$ \\
\hline $\begin{array}{l}\text { Kontrol positif (Amoxicillin } \\
25 \mu \mathrm{g})\end{array}$ & 23,00 & 21,00 & 21,00 & $\underset{\mathrm{d}}{21,66 \pm 1,15}$ \\
\hline
\end{tabular}

Keterangan: subscript yang berbeda menunjukkan perbedaan bermakna $(\mathrm{p}<0.05)$ dengan uji Mann Whitney taraf kepercayaan 95\%.

Tabel IV menunjukkan besar rata-rata zona hambat yang terbentuk pada masing-masing konsentrasi ekstrak perasan daun mengkudu. Pada konsentrasi $1,56 \%$ tidak terbentuk zona hambat. Zona hambat mulai terlihat pada konsentrasi $3,12 \%$ sebesar $2,50 \pm 0,86 \mathrm{~cm}$. Zona hambat tersebut menurut Davis \& Stout (1971) termasuk kategori lemah. Konsentrasi tersebut merupakan Kadar Hambat Minimal (KHM) pada ekstrak perasaan daun mengkudu, diikuti oleh konsentrasi $6,25 \% ; 12,5 \%$; dan 25\%. Semakin besar konsentrasi maka semakin besar pula zona hambat yang ditimbulkan (Prescott, 2005), namun besarnya masih lebih kecil dibandingkan dengan kontrol positif. Pada kontrol positif digunakan

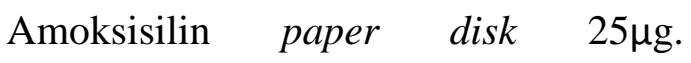
Amoksisilin merupakan antibiotik golongan penisilin dengan spektrum luas (Harianto, 2006). Penggunaan amoksisilin dalam ISK dapat diberikan apabila pasien mengalami kontra indikasi penggunaan kotrimoksasol, seperti reaksi alergi atau menderita gangguan fungsi ginjal. Kontrol negatif yang digunakan adalah akuades steril dan hasilnya tidak menimbulkan zona penghambatan. Hasil uji statistik menunjukkan bahwa terlihat adanya perbedaan yang bermakna dengan uji Kruskal Wallis dengan $\mathrm{p}=0,03(\mathrm{p}<0,05)$ dan dilanjutkan dengan uji Mann Whitney. Hasil pengamatan aktivitas antibakteri ekstrak perasaan daun mengkudu dapat dilihat pada Gambar 2. 


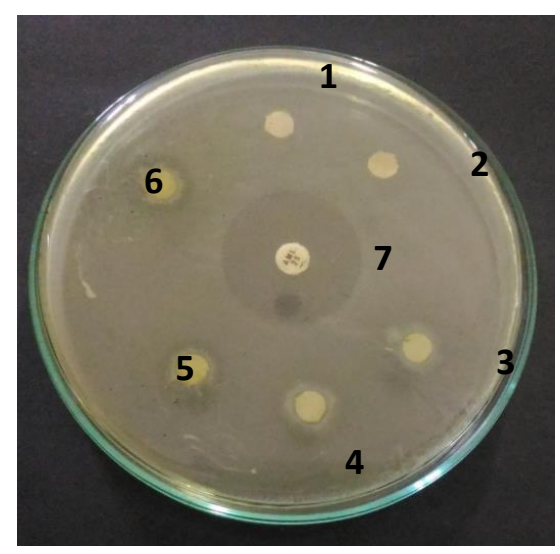

\section{Gambar 2. Hasil Aktivitas Antibakteri Ekstrak Perasaan Daun Mengkudu} Keterangan:

1. Kontrol negatif (akuades steril)

2. Ekstrak perasan daun mengkudu $1,56 \%$

3. Ekstrak perasan daun mengkudu 3,12\%

4. Ekstrak perasan daun mengkudu $6,25 \%$

5. Ekstrak perasan daun mengkudu $12,5 \%$

6. Ekstrak perasan daun mengkudu $25 \%$

7. Kontrol positif (Amoxicillin $25 \mu \mathrm{g}$ )

Perbedaan diameter zona hambat ekstrak perasan daun mengkudu dipengaruhi oleh konsentrasi senyawa zat aktif yang terdapat dalam ekstrak perasaan daun mengkudu. Mekanisme penghambatan pada bakteri E.coli pada ekstrak perasan daun mengkudu diduga berasal dari kandungan senyawa flavonoid dan antrakuinon. Mekanisme kerja flavonoid menghambat fungsi membran sel dengan cara membentuk senyawa kompleks dengan protein ekstraseluler dan terlarut sehngga merusak membran bakteri yang diikuti keluarnya senyawa intraseluler (Nuria dkk, 2009). Antrakinon bekerja sebagai antibakteri dengan cara mempengaruhi sintesis sel bakteri E.coli. Antrakinon merupakan suatu persenyawaan fenolik yang mekanismenya serupa dengan golongan fenol, yaitu menghambat bakteri dengan cara mendenaturasi protein (Fitri, 2005).

\section{SIMPULAN}

Kesimpulan dari penelitian ini adalah :

1. Ekstrak perasaan daun mengkudu mempunyai aktivitas antibakteri terhadap E.coli.

2. Besarnya Kadar Hambat Minimal (KHM) pada ekstrak perasaan daun mengkudu pada konsentasi 3,12\% dengan zona penghambatan sebesar

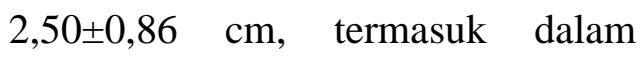
kategori lemah (Davis \& Stout, 1971).

\section{DAFTAR PUSTAKA}

Anief, M. 2010. Ilmu Meracik Obat. Gadjah Mada University: Yogyakarta.

Davis \& Stout. 1971. Disc Plate Method of Microbiological Antibiotic 
Essay. Journal of Microbiology.

DepKes RI, 2000. Parameter Standar Umum Ekstrak Tumbuhan Obat. Edisi I. Direktorat Pengawasan Obat Tradisional: Jakarta.

Fitri, DN. 2005. Studi Tentang Daya Hambat Ekstrak Lidah Buaya (Aloe vera) dengan Konsentrasi yang Berbeda Terhadap Pertumbuhan Bakteri Aeromonas hydrophila Secara In vitro. Skripsi. Jurusan Perikanan. Fakultas Peternakan Perikanan. UMM. Malang.

Harborne, J.B. 1987. Metode Fitokimia Penuntun Cara Modern Menganalisis Tumbuhan. Penerbit ITB: Bandung

Harianto., 2006. Perbandingan dan Harga Tablet Amoxicilin 500 mg Generik Dengan Non Generik Yang Beredar Di Pasaran. Majalah Ilmu Kefarmasian. 3(3): 127-142.

Jawetz, Melnick \& Adelberg. 2014. Mikrobiologi Kedokteran Edisi 25. Salemba Medika: Jakarta.

Kameswari, M. S., Mahatmi, H., \& Besung, K.N., 2013. Perasan Daun Mengkudu (Morinda citrifolia L.) Menghambat Pertumbuhan Bakteri E.coli Secara In Vitro. Jurnal Indonesia Medicus Veterinus. 2(2):216-224.

Nuria, M.C., Faizaitun, A.,\& Sumantri, 2009. Uji Aktivitas Antibakteri Ekstrak Etanol Daun Jarak Pagar (Jatropha curcas L) Terhadap Bakteri
Staphylococcus aureus ATCC 25923, Escherichia coli ATCC 25922, dan Salmonella typhi ATCC 1408, Mediagro. 5(2):26-37.

Putra, Nusa. 2012. Metode Penelitian Kualitatif Pendidikan. Raja Grafindo Persada: Jakarta.

Rukmana, HR. 2002. Mengkudu Budidaya dan Prospek Agribisnis. Kanisius.

Sari R.P. 2018. Angka Kejadian Infeksi Saluran Kemih (ISK) dan Faktor Resiko yang Mempengaruhi pada Karyawan Wanita di Universitas Lampung, Skripsi. Universitas Lampung: Lampung.

Sirait, M. 2007. Penuntun Fitokimia Dalam Farmasi. ITB : Bandung. Sutriani, L. 2008. Teknik Pembelajaran Fitokimia. Universitas Muhammadiyah: Semarang.

Wahyudi, Irfan, 2015, Guideline Penatalaksanaan Infeksi Saluran Kemih dan Genitalia Pria: Infeksi Saluran Kemih Pada Anak, Ikatan Ahli Urologi Indonesia, Surabaya.

Wiradona, I., Suwarsono, \& Sunarjo, L., 2015, Pengaruh Perasan Mengkudu Terhadap Pertumbuhan Bakteri Staphylococus aureus. Jurnal Kesehatan Gigi. 2(1):8-13. 